Fish biology

\title{
STUDIES ON THE EFFECT OF PREY DENSITY ON THE SATIATION TIME OF A COMMON FRESHWATER PREDATORY FISH CHANNA STRIATA (BLOCH)
}

\section{BADANIA NAD WPEYWEM LICZEBNOŚCI OFIAR NA CZAS NASYCENIA SIĘ POKARMEM POSPOLITEJ SŁODKOWODNEJ RYBY DRAPIEŻNEJ CHANNA STRIATA (BLOCH)}

\author{
Department of Aquatic Biology and Fisheries, Trivandrum, India
}

\begin{abstract}
The satiation amount of food and satiation time of three size groups of fish were studied and were found to vary with variations in prey density. The reasons for this variation are discussed.
\end{abstract}

\section{INTRODUCTION}

Fishes belonging to the family Channidae are important freshwater food fishes of Asia (Wee, 1981). In India, this fish is caught from rivers, ponds inundated paddy fields and swamps. Recently attempts are being made to culture them in controlled conditions. Channa striata is a predatory fish and hence knowledge about the predatorprey relationship will be interesting and useful. Any attempt to culture this fish would require an understanding of its protein requirement and without knowing the amount of food required to satiate, no feeding rate can be established accurately (Pandian, 1967). Of the several factors, affecting satiation amount and time, the population size of the predator and prey is specially important in predatory forms.

Although detailed investigations on factors affecting food intake, digestion and absorption have been carried out (Wee, 1981) no information exists regarding the vital point of satiation amount and time of this fish. Moreover, in the natural habitat, a few observations on the cost benefit analysis in foraging shoals have been made in temperate fishes and no such study exists in tropical situations. Though some costs and benefits in foraging shoal have been recently explored quantitatively (Krebs, 1978; Pitcher et al., 1983; Fretwell and Lucas 1970; Parker, 1973; Milinski, 1979 and Sutherland, 1983), theoretical behavioural ecology has yet to make testable predictions in 
this area (Pitcher, 1986). It is also found that the antipredator function of shoaling has not much experimental proof. This paucity of information prompted a study on the effect of prey density on the satiation amount and time which would provide not only clues for feeding them in culture systems but also reveal their predatory behaviour in natural habitat.

\section{MATERIAL AND METHODS}

Specimens of C. striata ranging from $0.1 \mathrm{~g}$ to $150 \mathrm{~g}$ were collected from paddy fields and ponds for the study. They were grouped into fry ( 0.1 to $1 \mathrm{~g}$ ), fingerlings ( 1 to $2 \mathrm{~g})$ and adults $(30-150 \mathrm{~g})$ and were left for acclimation in separate cement cisterns for a period of two weeks. The cisterns were filled with fresh water pumped from a neighbouring well, the temperature of which remained $27 \pm 2^{\circ} \mathrm{C}$ and dissolved oxygen near air saturation. The fish during this period were fed small live fishes in the case of adults and mosquito larvae and minsed trash fish in the case of fry and fingerlings. The prey used for the experiment with adult fish were live Puntius ticto, a small fish of almost the same size and mosquito larvae of the 3rd instar for fry and fingerlings.

For the experiments with the adult fish, glass tanks of 100 litres capacity were used and for fry and fingerlings troughs of 3 litres and 5 litres capacity respectively were used. The experimental tanks were filled with freshwater and were covered with black paper from all sides except for an observation window.

Before introducing the predators into the experimental tank they were starved for $48 \mathrm{~h}$ for gut evacuation and were also weighed to the nearest milligram. Weight of the prey fish and mosquito larvae were also noted accurately. The density of the predator per experimental tank was constant while the density of the prey individuals.

The prey density was maintained as 50,100,200,300, 400 and 500 individults of fish $/ \mathrm{m}^{3}$ in the case of adults and $800,1600,3200$ and $6400 / \mathrm{m}^{3}$ of mosquito larvae in the case of fingerlings and $1600,3200,6400$ and $12800 / \mathrm{m}^{3}$ of mosquito larvae in the case of fry. In each of the fixed prey density the satiation amount and satiation time were recorded.

Satiation has been defined (Brett, 1971) as that state in which an animal no longer accepts any food, in the presence of excess, after a period of active feeding and the time from the start of feeding to such voluntary cessation is considered the satiation time. In the present study maintaining the predator density as constant for all the three size groups, in the above mentioned densities, the satiation amount was determined by noting the number of prey consumed during a period of active feeding; starting right from the introduction of the predator into the experimental tank to voluntary cessation of feeding. The size of the prey being same the total amount of food consumed was calculated from the number of prey consumed. The mean satia- 
tion amount of each fish divided by its weight gave the amount consumed per gram body weight. The satiation time was recorded by starting a stop-watch at the time of introduction of predator to the experimental tank and stopping it on rejection. The prey densities were maintained constant by introducing the prey, soon after consumption. Ten replicates were tested for each experiment.

\section{RESULTS}

The satiation amount of adult $C$. striata when exposed to different densities of prey is represented in Fig. 1. In adults the satiation amount was found to be influenced by prey density. Given the same conditions except for different densities of prey, the amount of food (prey) required to satiate the fish increased from $3.45 \mathrm{mg} / \mathrm{g}$ body wt. at $50 \mathrm{prey} / \mathrm{m}^{3}$ to $4.96 \mathrm{mg} / \mathrm{g}$ body wt. at $100 \mathrm{prey} / \mathrm{m}^{3}$ and subsequently decreased to $2.22 \mathrm{mg} / \mathrm{g}$ body wt. at $500 \mathrm{prey} / \mathrm{m}^{3}$.

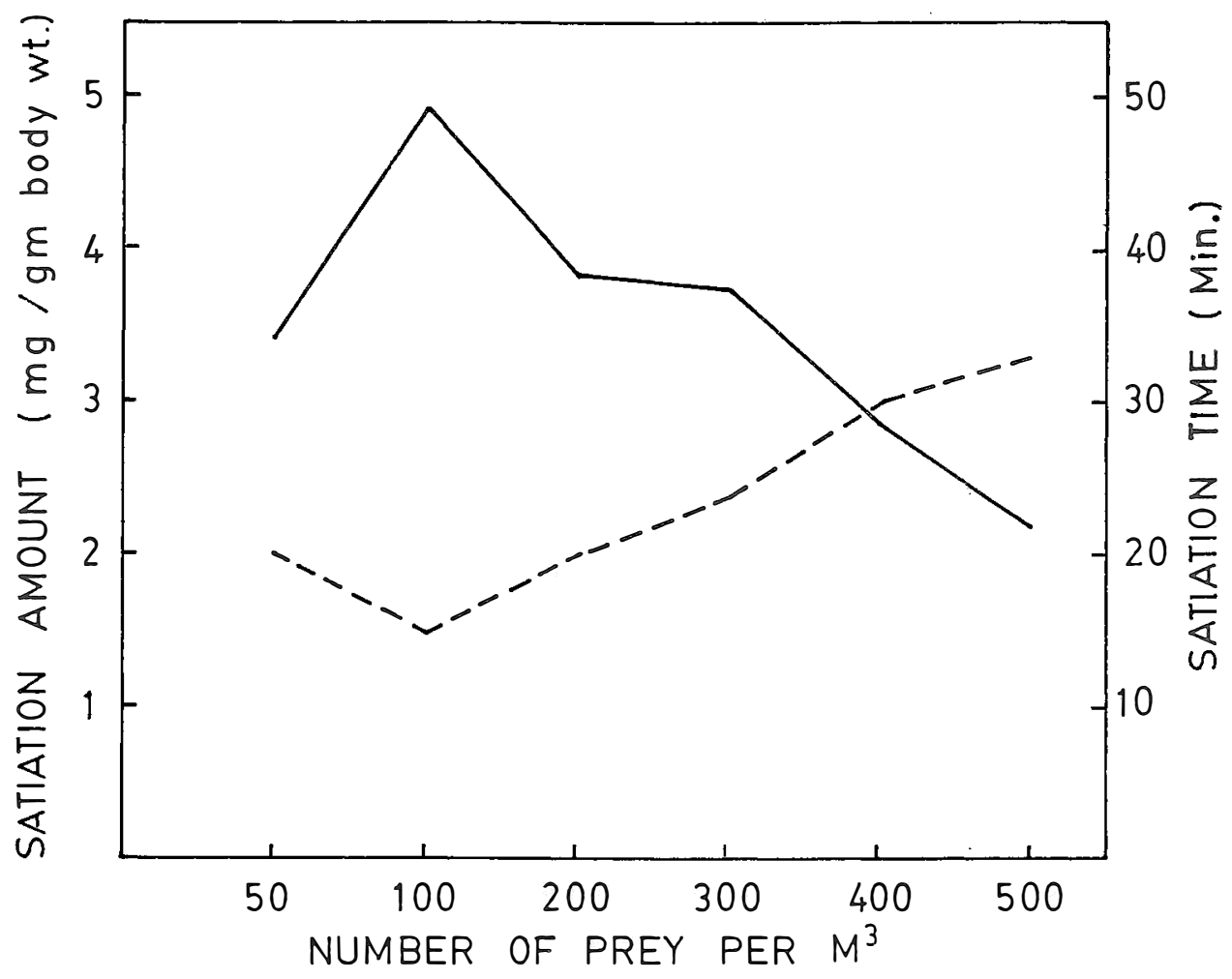

Fig. 1. Effect of Prey Density on the satiation Amount and satiation time in the adults of C. striata 


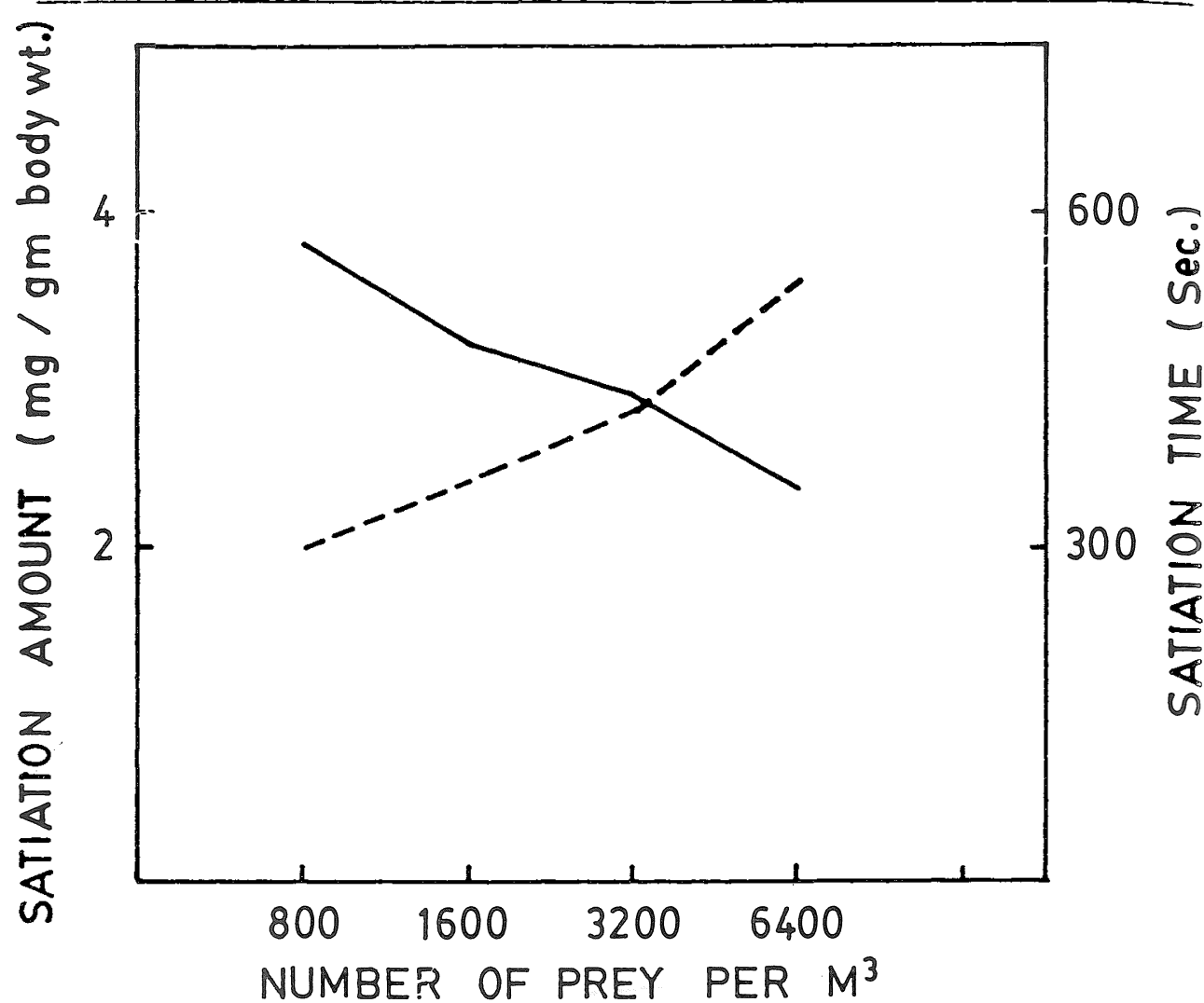

Fig. 2. Effect of Prey Density on the satiation Amount and satiation time in the fingerlings of C. striato

The satiation amount of food in the case of fingerlings and fry feeding on mosquito larvae at different prey densities is presented in Figs. 2 and 3 respectively. In both cases the satiation amount decreased with increase in prey density. In the case of fingerlings the amount of food required to satiate was found to be $3.82 \mathrm{mg} / \mathrm{g}$ body wt. at $800 \mathrm{prey} / \mathrm{m}^{3}$ which decreased to $2.34 \mathrm{mg} / \mathrm{g}$ body wt. at $6400 \mathrm{prey} / \mathrm{m}^{3}$. In fry, the satiation amount decreased from $15.83 \mathrm{mg} / \mathrm{g}$ body wt. to $5.7 \mathrm{mg} / \mathrm{g}$ body wt. as the prey density increased from $4600 \mathrm{prey} / \mathrm{m}^{3}$ to $12.800 \mathrm{prey} / \mathrm{m}^{3}$.

The relationship between prey density and satiation time in adults, fingerlings and fry are presented in Figs. 1,2 and 3 respectively. The satiation time showed a direct relationship with prey density in fingerlings. In fingerlings the satiation time increased almost steadily from the minimum value of $300 \mathrm{secs}$. at $800 \mathrm{prey} / \mathrm{m}^{3}$ which was the lowest density studied, to 360 secs., 420 secs. and 540 secs. at 1600, 3200 and 6400 prey $/ \mathrm{m}^{3}$ respectively. However, the adults and fry showed an initial decline with increase in prey density and further increase in prey density in both cases was accompanied by an increase in the satiation time. In adults it declined from 30 minutes to 


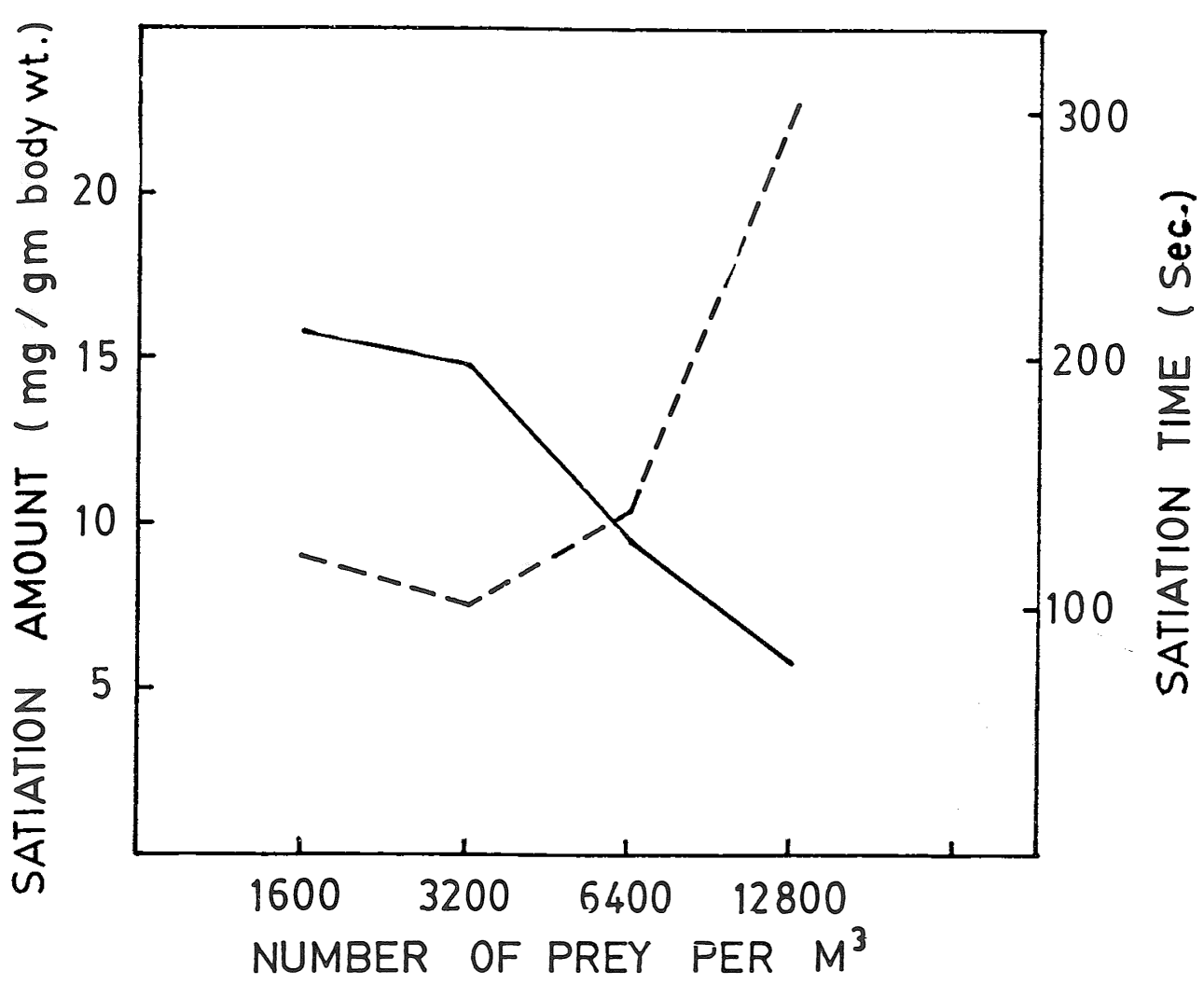

Fig. 3. Effect of Prey Density on the satiation Amount and satiation time in the fry of C. striato

15 minutes as prey density increased from 50 to $100 \mathrm{prey} / \mathrm{m}^{3}$. Further increase in prey density to $200,300,400$ and $500 \mathrm{prey} / \mathrm{m}^{3}$ showed an increase in satiation time to 20,24 , 30 and 33 minutes respectively. In fry the decline in satiation time from $120 \mathrm{sec}$. to 100 sec. was noticed as prey density increased from 1600 to 3200 prey $/ \mathrm{m}^{3}$. Further increase in prey density to 6400 and $12800 \mathrm{prey} / \mathrm{m}^{3}$ showed an increase in satiation time to 140 and $300 \mathrm{sec}$. respectively.

\section{DISCUSSION}

Many factors have been found to affect satiation amount of food in fishes. Wide variation in satiation amount and satiation time occur between species due to the difference in their stomach capacity, type of food (Ivlev, 1961 and Le Brasseur, 1969), size of the fish (Ishiwata, 1968a) and the quantity of food available in the habitat (Ishiwata, 1968b). In predatory fishes food intake involves chasing, capturing and handling the prey. Hence the energy required in feeding is considerably high. Results 
of the present study indicate a consistent decrease in satiation amount with increase in prey density. Nair and Nair (1982) have shown a reduction in satiation amount even when sedentary food items were offered in bulk. In the present study, C. striata was of fered wriggling mosquito larvae and fast moving fishes in increasing densities and the relative availability of prey per fish in each density was kept constant during feeding. In such a situation the response of the fish was a reduction in satiation amount and an increase in satiation time. One of the reasons for this seems to be the 'confusion effect' (Milinski, 1979) the prey creates in high densities which negatively interferes with the attack response on multiple targets. This decline in attack success with increasing prey density has been demonstrated in Piscivorous fishes (Neill and Cullen, 1974; Nair and Nair, 1982; Magurean and Pitcher, 1986). As Guthrie (1980) put it, visual predators rely on complex movements and targetory analysis and it is difficult for them to overcome the perceptual confusion effect. Moreover, according to the optimal foraging theory (Pike et al., 1974; Krebs, 1978) natural selection will favour predators that minimise energy spent to capture its prey so that the energy required for other activities like growth can be budgeted more effectively. Our results on the effect of prey density on the satiation time also agrees with this. Although C. striato is an efficient predator, its efficiency to obtain food decreases when met with large schools of prey fishes. Satiation time also involves time spent for chasing, capturing and handling the prey and hence involves a greater expenditure of energy which the fish reduces after a certain level for saving energy.

\section{CONCLUSIONS}

1. The density of prey in the environment influences the quantity of food required to satiate this predatory fish.

2. As the prey density increases the satiation amount decreases irrespective of the size of the predator.

3. The time required for satiation increases as prey density increases in the all size groups.

4. The 'Confusion effect' created by large numbers of prey seem to be responsible for interfering with the attack response which results in decreased satiation amount and increased satiation time in higher prey densities.

\section{ACKNOWLEDGEMENTS}

The authors are thankful to Dr. P. Natarajan, Head of the Department of Aquatic Biology and Fisheries, University of Kerala, for providing facilities required during the tenure of this work.

One of us (B.M.) is thankful to the University of Kerala for providing a J.R.F. 


\title{
REFERENCES
}

Brett J.R., 1971: Satiation time, appetite and maximum food intake of Sockeye salmon (Onchorhynchus nerka), J. Fish. Res. Bd. Canada, 28: 409-415.

Fretwell S.D., M.L. Lucas, 1970: 'On Territorial behaviour and other factors influencing habitat distribution in birds'. Acta Bioeoretica, 19: 16-36.

Guthrie D.M., 1980: Neuroethology: an Introduction, Blackwell, Oxford, 221 pp.

Ishiwata No, 1968a: Ecological studies on the feeding of fishes - V. Size of fish and satiation Amount, Bull. Jap. Soc. Scientific Fish., 34, 9: 781-784.

Ishiwata Nog, 1968b: Ecological studies on the feeding of fishes - VI. External factors effecting satiation amount (1), Bull. Jap. Soc. Scientific Fish., 34, 9: 785-791.

Ivlev V.S., 1961: Experimental ecology of the feeding of fishes, Yale University Press, New Haven.

Krebs J.R., 1978: 'Optimal foraging: Decision rules for predators', J.R. Krebs and N.B. Davies (eds.), Behavioural Ecology Ist edn, Blackwell, Oxford, 23-63.

Le Brasseur R.J., 1969: Growth of juvenile chum salmon (Onchorhynchus keta) under different féeding regimes, J. Fish. Res. Bd. Can., 26: 1631-1645.

Magurran A.E., T.J. Pitcher, 1986: 'Provenence, shoal size and the organisation of predator aevasion behaviours in Minnow Shoals' (submitted).

Milinski M., 1979: 'Can an experienced predator overcome the contusion effect of swarming prey', Anim. Behar., 27: 1122-6.

Nair J.R., N.B. Nair, 1982: Effect of teleostean prey size and salinity on satiation amount, satiation time and daily ration in the glassy Perchlet Chanda (=Abassis) thomassi (Day) (Pisces: centropomidae), Proc. Indian Acad. Sci. (Anim. Sci.), 91, 6: 507-513.

Neill S.R., J.M. Cullen, 1974: 'Experiments on whether schooling by their prey affect the hunting behaviour of Cephalopod and Fish Predators', I. Zool. (London), 172: 549-69.

Pandian T.J., 1967: Intake and digestion, absorption and conversion of food in Megalops cyprinoides and Ophiocephalus striatus, Mar. Biol., 1: 16-32. Size and the Organisation of Predator Evasion Behaviours in Minnow Shoals' (submitted).

Parker F.R., 1973: 'Reduced Metabolic Rate in Fishes as a result of Induced Schooling, 'Transactions of the American Fisheries Society, 102: 125-31.

Pitcher T.J., 1986: 'Functions of shoaling behaviour', T.J. Pitcher (edtd.), The behaviour of Teleost Fishes Croom Helm, London and Sydney: 294-337.

Pitcher T.J., A.E. Magurran, J.R. Allan, 1983: 'Shifts of Behaviour with shoal size in Cyprinids', Proceedings of the British Freshwater. Fisheries Conference, 3: 220-228.

Pyke G.H., H.R., Pulliam, E.L. Charnor, 1977: 'Optimai Foraging: a selective review of theory and tests', Quat. Rev. Biol., 52: 137-154.

Sutherland N.S., 1983: 'Aggregation and the Ideal Free Distribution', J. Anim. Ecol., 52: 821-828.

Wee K.L., 1981: A case study of snakehead (Channa striatus) farming in Thailand, Internal report of Institute of Aquaculture, University of Stirling.

\author{
Bindoo Mathen, C.M. Aravindan
}

\section{BADANIA NAD WPEYWEM LICZEBNOŚCI OFIAR NA CZAS NASYCENIA SIĘ POKARMEM POSPOLITEJ SŁODKOWODNEJ RYBY DRAPIEŻNEJ CHANNA STRIATA (BLOCH)}

\section{STRESZCZENIE}

Niniejsza praca zawiera wynik badań nad ilością pokarmu oraz czasem nasycenia się w trzech grupach ryb o różnej długości ciała. Wielkości te ulegały zmianom wraz z różną liczebnością ofiar. Stwierdzono, że liczebność ta w środowisku wpływa na ilošć pokarmu potrzebnego do nasycenia głodu ryb. Kiedy wzrasta za 
gęszczenie ryb stanowiących pokarm Channa striata (Bloch), zmniejsza się wówczas ilość pokarmu potrzebnego dla zaspokojenia ich głodu, bez względu na długošć drapieżnika. Czas potrzebny do nasycenia głodu wzrasta wraz ze zwiększeniem liczebności ofiar we wszystkich grupach długości drapieżnika. Tzw. "efekt nadmiaru”, spowodowany przez dużą liczbę ofiar jest przyczyną zmniejszonej presji drapieżników na ryby, co spiawia, że zmniejsza się ilość pokarmu a wydłuża się czas nasycenia przy wyższych liczebnościach ofiar.

Author's address:

Received: 1991.09.12

Bindo Mathen and C.M. Aravindan

Department of Aquatic Biology \& Fisheries

University of Kerala

Thiruvananthapuram, India 695007. 